\title{
The Role of Foreign Policy and International Relations in Economic Development Based on the Philosophy of Liberalism
}

\author{
Mohammadreza Agharebparast (Corresponding author) \\ Assistant Professor, Department of Politics and International Relations, Islamic Azad \\ University, Shahreza Branch, Shahreza, Iran
}

\begin{abstract}
Ahmad Zeinali
MA of International Relations, Department of Politics and International Relations, Islamic Azad University, Shahreza Branch, Shahreza, Iran
\end{abstract}

Received: July 6, 2016 Accepted: August 8, 2016 Published: August 10, 2016

doi: 10.5296/jsss.v4i1.9706 URL: http://dx.doi.org/10.5296/jsss.v4i1.9706

\begin{abstract}
The national economic growth is one of the most important development indicators that are affected by a variety of factors including the international relations. International relations consist of a series of actions and interactions of the government and non-government an institutions and political processes of the nations. However, international politics refers to the governmental behaviors or their reactions. On the other hand, and foreign policy includes a set of governmental decisions concerning the foreign relations. Liberalism is a comprehensive view that covers the domestic and foreign policies and is the theoretical framework of this study to discuss the economic development. This library study aimed to investigate the role of the international relations in economic development and analyzed a wide range of the theories or discussions. Review of literature showed the role of the international relations in the economic development of the societies. Furthermore, according to the theory of liberalism, all the countries in the world are interdependent and if this kind of interdependence is efficiently managed using a comprehensive framework it may lead to the economic development.
\end{abstract}

Keywords: International relations, International policy, Economic goals 


\section{Introduction}

Economic development is a prerequisite for the survival and prosperity of a social and political system that is measured by a variety of indicators. Per capita product growth in the society, rates of unemployment and inflation, individual income distribution, the average educational level of the labor force, access to education and health services, life expectancy, level of cultural products, to earn a living during the retirement and unemployment are of the indicators of the economic development (Mashayekhi, 2013).

Economic growth implies the increased production or national income. If the production of the goods or services increases in a country, the country's economic growth takes place. Economic development may be interpreted as the increased production of a country in a certain year compared to its rate in the base year. At the macro level, the increase in the gross national product (GNP) or the gross domestic product (GDP) in a certain year compared to its rate in the base year is called economic development. The prices in a base year are used for calculating the economic development because the calculated increase of the GNP is affected by the increase of the production rate and the effect of the price increase or inflation is removed (Chu, 2012).

In the modern world, economic development is based on the unprecedented growth of the science and technology. The rapid development of the science and technology results from all human efforts in different parts of the world. Firms, research centers and universities, scientists, industrialists and managers of all parts of the world play a key role in every day discoveries and innovations. Producers concentrate on supplying the certain products that are not produced in different countries due to their copyright. There is a kind of labor division in human societies. A number of countries due to their accessibility to the certain resources or special skills, knowledge and patents, produce a variety of products that are not cost-effective to be produced in other countries. Generally, different countries exchange their goods and services and go forward. With market access for goods and services in other countries, the scale of production maybe increased and lead to the more economic production. The exchange of the knowledge, technology, capital, goods, and services in these countries facilitate their economic development. Nowadays, and economic development is not achieved without the world interaction (Mashayekhi, 2013).

Politics has been conceptualized in variety of ways notably in dictionaries of political sciences. Science of politics may be defined in two ways: firstly, as a common concept related to the human kind in all societies, regardless of the ideological, intellectual orientations and the socially accepted values. Secondly, as an acceptable case that is affected intellectually and ideologically by those who define it; however, it is not accepted in other societies and is not considered true (Eskandari, 1999).

Foreign policy is the most important international behavior of the governments. It refers to the deliberate efforts of the countries through which they seek to increase, preserve, and display their international power and is a strategy or a series of planned actions that are designed by the decision makers in each country with the aim of achieving the specific objectives that are defined in terms of the national interests (Tajik, 2004). It is also as an international communication link. Although foreign affairs differ from the domestic policy, it is considered as the supplementary element for the national policy that seeks to promote 
legitimacy, prestige in the international affairs, and managing and influencing the public opinions in other countries.

Nowadays, economic development requires the economic and scientific cooperation with other countries. If the senior managers think of the development-oriented policies, the international relations in a country are managed so that its political independence is preserved and economic interaction with other countries is facilitated and leads to the economic development of that country. On the regulation of international relations, the development of the market for domestic products, access to the technology and knowledge for the national economy, the possibility of attracting the foreign capital and international sources and, finally, the economic interaction and trade for the economic development are prioritized (Mashayekhi, 2013).

At present, the most debatable issues in the international relations can be divided into at least three groups of paradigms: realism, pluralism, and structuralism. Of course, these paradigms are differently named by other theorists, too, for instance, Ruesna' taxonomy is the most important one: state-centric, multi-centric and global-centric (Ruesna, 1995).

Today, when studying the international relations, theorists focus on the systemic approach that has been proposed by Moregenta (2000) and neo-realists such as Waltz (1979), among others. This approach emphasizes on two main issues: rationality and using the nation-state interface for analysis (Sylvan, 1998). Neo-realism in modern international studies that is also called the theoretical system is based on the above-mentioned framework.

In the early years of the 1960, American radical theoretical tendency for the experimental and quantitative studies, which emphasized on the use of the statistical methods, interviews and so on that is so-called behaviorism. They clarified the hypotheses that were are testable and sought for the general theories. Since the late 1960s, those who opposed to this method could develop the theoretical studies as usual and beyond the quantitative methods. Of course, this was not the end of the quantitative and qualitative studies and this discussion continues. Few main issues should be considered in the studies of international relations:

1) The role of the states has been one of the most controversial issues in the last two decades. Realistic viewpoint that considers the states as the units of the analysis is mainly criticized. Here, the role of the multi-national organizations in many countries is discussed. These organizations do not belong to a certainstate and they are even bigger and more powerful than the states and are called transnational organizations.

2) Distinguishing between the national and international factors in the international studies is another issue that is partly related to the concept of the interdependence and has been discussed by a number of scholars such as Nye. They believe that the national and international factors could not be distinguished and their close relationships should be considered.

3) Another issue that is covered in the international relations is the importance and the role of economic issues and with regard to the previous issues, a number of studies has been conducted in the field of the international political economy, for example, Strange. She believes that the international political economy is a multi-disciplinary science that considers the non-state players including the multinational organizations, and those who 
are not regarded as a political unit that governs a certain country. According to Strange, the second group includes the NGOs, Mafia Networks, and contraband.

4) A number of main issues that have been discussed over the recent years are as follow:

Terrorism and of international relations;

critical theory and international relations;

future trend of the international relations concerning the relationship between the international economy and international policy (including the interactions of the international political economy, analysis of the foreign policy, and strategic studies); and The relationship between security and energy supply.

5) Another issue is to clarify the relationship between the policymaking within the country and the performance of the foreign policy. This necessitates to develop the working scope of the foreign policy system and to conduct a number of studies that cover the bureaucratic policies, group thinking and belief systems in foreign policy. However, this has two policymaking outcomes that is often ignored:

More attention to the implementing the policies; because most of the foreign policy models have focused on policymaking, as if it is the true case of the foreign policy. Only in two recent periods, the outcomes of the foreign policy have been emphasized.

The models, which concentrate on the decision-making, should integrate a number of reasons of the middle level. The main issue is that the relationship between the mechanistic behavioral models such as the bureaucratic policies should be clarified with regard to the worldwide attitudes of the players.

\section{Theories of the International Relations}

\subsection{Constructivism}

One of the most important topics in the theory of constructivism, is the way that norms, identities, nation's interests are formed and affect the foreign policy. Constructivists believe that all individual actions and reactions happen in the social environment and lead to the decision-making. Therefore, foreign policy is what the states make, decide about, interpret, declare, and finally implement (Smith, 2001). This theory by rejecting the material factors that are considered by the classic realists, emphasize on the rules, values and discourses and believe that identities determine the interests. Constructivists believe that in addition to the national factors, international structure plays a key role in determine the trends of the foreign policy.

\subsection{Realism}

Realism as the main theory of the international relations due to its focus on the reality of the international relations has been frequently considered by the policymakers and decision makers of the foreign policy. The basic assumptions of this theory by focusing on national interests are as follow:

- As the clues for foreign policy of the countries

- As the clues for the states as the main players of the international system

- Domineering nature of the human beings 


\section{Macrothink}

Journal of Social Science Studies

ISSN 2329-9150

2017, Vol. 4, No. 1

- The role of the powerful states in establishing the relations and decision making in foreign policy

- Foreign policy as a tool for achieving the national interests and increasing the national power of the countries

- Considering the interests based on the power

- The lack of the importance of ethics and international norms in international relations

- Anarchic international system; and

- $\quad$ Finally, survival as the ultimate goal of the states (Wohlforth, 2008).

\subsection{Liberalism}

Classic liberalism, unlike the classic realism believes in the good nature of the human beings and the interaction and cooperation between the states. This theory assumes that order within the countries may lead to the order in the international system and consequently, international peace. In addition, expansion of the free market and the interdependence of the states can prevent war. Woolf states that although the world trade in itself may not lead to the peace, increasing trade interdependence plays an important role in decreasing the costs of war (Smith, 2001) and preventing the war.

One of the central ideas of the theory of liberalism is the role of decision makers on foreign policy. Liberalism by considering the states as the main players in the international system, emphasize the role of others, including individuals, groups, multinational companies and NGOs in the process of foreign policy making. It states that by increasing the number of the players, the authority of the states is decreased and the international system moves toward a civilized society and by rejecting the interests of the states, relates it to the negotiations of the states. In addition to the role of NGOs, the role of the international institutes in the process of the decision-making on foreign policy is of particular importance (Keohane and Nye, 1973). Therefore, liberalism explains that decision-making on foreign policy is not confined to the internal factors of the states, but the external factors are important, too.

The most important aspect of the liberal theory is to believe in transformation in international relations by cooperation, reducing the conflicts, and finally achieving the world peace. Liberalism is generally divided into four categories: liberal internationalism; idealism; liberal institutionalism; and neo-liberal institutionalism. In spite of the differences, the main issues that are considered in these four categories are as follow:

1) Democratic peace that focuses on changing the political structure of the societies in order to achieve the peace

2) Trans-nationalism that focuses on the role of the new activists in international arena, thereby changing the international policy

3) Focusing on the role of the trade communications in preventing the war and achieving the peace

4) Institutionalism by focusing on the role of the international institutions for significant international transformations (Moshirzadeh, 2007).

\subsection{Ontology}

Liberalism derives its philosophical and anthropological ideas from the philosophical 
thoughts of the stoicism and teachings of the Christianity, notably San Pierre in $18^{\text {th }}$ century that Kant discussed them from a philosophical viewpoint. While stoicism focused on the good nature of human beings and hoped for peace, Kant introduced wisdom. He believes that people seek for freedom and achieve the peace. Therefore, according to realism, power orientation and state-orientation caused the war in the international relations; however, idealism emphasized on the economic and cultural relationships and eliminating the powerorientation and state-orientation in order to prevent the war (Schemidt, 2002)

Idealism mainly assumes that the factors that cause the peaceful relationship of the people are more important than those that cause the conflicts. Idealists reject the idea that considers the states as the source of the moral values. They emphasize on the cosmopolitan ethics and try to teach people to do international reforms (Wanger, 2008).

Since long time ago, two general and pervasive attitudes of liberalism and realism have been considered as two kinds of dominant discourse in theorizing of the international relationships and the way of the foreign policy making. Both of these, discuss the international relations differently, from the philosophical (ontological) and anthropological viewpoints. The way realism discusses the human beings, politics and society lead to the war-orientation in international relations; however, idealism (liberalism) focus on peace in the international relations and war is a causal situation.

All of the approaches in theories of the international relations are meta-theoretically (ontologically, epistemologically and methodologically) distinguished and interpret the nature of the international relations differently. Islamic approach of the international relations is not an exception. Indeed, two major schools of the international relations are materialistic and focus on the objectivities.

\subsection{Liberalistic Paradigm in International Relations}

Although liberalism has played a key role in world policy since the 17 th century onwards, the thought of liberalism in international relations was manifested in a framework of the idealism in the interval of the World War I and World War II (Powell, 2009). Like realism, liberalism is not an integrated and comprehensive theory. Due to the most important conflicts in the liberal tradition concerning a variety of issues such as human nature, the reasons for the war and the relative importance of the people, states and international institutions, a number of liberal approaches are here discussed (Dai, 2008).

With regard to the impact of the liberalism on the economic goals, it can be said that liberalism considers the role of states in the international policy but not as the main players. It assumes that there are a number of transnational players, too, including the international organizations, multinational companies, associations, international regimes and so on (Suganami, 2009).

Concerning the existence of the order in the world policy, they believe that this kind of order is not the result of the balanced power system, but it is originated from a number of factors including

Laws, norms agreed upon, institutional regulations, and the international regimes (Danilovic, 2009). Therefore, all the states can play a key role in world policy and achieve their economic goals using a foreign policy and with regard to the effective role of the transnational players. 


\subsection{Foreign Policy}

Nowadays, a there is a variety of issues in international relations, but they may be divided into at least three groups of paradigms: state-centric, multi-centric and global-centric (Ruesna, 1995). In the foreign policy, there is a similar model including the realism, idealism and globalism (Sergiun, 2000). The global system, international relations, and international players (and not the states) is not comparable with the international relations over the recent decades. Foreign policy and the factors that contribute the process of policymaking are more important than before. There is a high rate of the actions, reactions, and interactions between the different countries. In the first years of the third millennium, international relations are considered as the main factor of the survival of the countries (Baharkeik, 2000).

Foreign policy covers the activities of a country in the foreign environments (Halsty, 1982). Therefore, it may be considered as strategy or a series of the planned activities that are conducted by decision makers of a country in relationship with other countries of the international institutions in order to achieve the national interests. Foreign policy is a process including the certain goals, certain foreign factors dependent on the above-mentioned goals, ability of a country in achieving the desirable results, developing a useful strategy, implanting the strategy, evaluating, and controlling the strategy (Jack, 1988).

The most important factor of the national authority is the quality and the way diplomacy is used. Although it is a factor of instability, it can be said that other factors that determine the national power are the basics of the national authority. Diplomacy is the body of the national authority, and national spirit is the soul. Quality of the diplomacy should be considered by the sates as the catalyze for different factors that play a role in their authority.

Using the traditions and customs, instead of the well-known people, ensures the diplomacy quality (Seifzadeh, 2005). Modern globalization, classic and traditional structures in all arenas has revolutionized the diplomacy. This transformation is not the end of all the traditional diplomatic phenomena, but it leads to the new concepts, methods, and structures of diplomatic relations.

Unlike the traditional diplomacy, which was absolutely determined by the states, diplomatic relations in the postmodern era suffer from increasing complexity (Sajadpoor, 2004). Information age challenges the classical diplomacy based on the real policy and strict authority. Therefore, the modern diplomacy policy is based on the thought-based politics. Cyberspace, intellectual and informational spaces are the result of the technologic, institutional and normative transformations in the era of the global policy (Vahidi, 2007). All the countries using an adaptable diplomacy try to achieve the maximum rate of the interests. Iran is not an exception, too. It needs to adopt an intellectual and informed policy not only to ensure its survival but also to promote its national authority in technological and economical arenas.

\section{Methodology}

This is a library study based on the literature. The library research method is commonly used in all scientific studies and maybe used in all sections of a study of this kind. It is also used in a number of studies that are not of library type. Literature and research questions should be particularly studied in this kind of the studies. Note taking is used for registering the results, 
explanatory in addition to the tables and forms.

\section{Discussion and Conclusion}

This study aimed to investigate the role of the foreign and international policy in economic development based on the liberalism viewpoint. Primarily, international relations were analyzed and a number of the theories of international relations were discussed. Finally, the role of the foreign and international policy in economic development was taken into account and clarified. Foreign policy and international relations are of the effective factors on the economic development of a society and cause the economic growth. Therefore, the national potentials should be prioritized and then international relations should be considered.

It can be said that in the globalized era, diplomacy is one of the main tools for promoting the national authority of the countries. New developments of the globalization era and increasing awareness has led to the cooperation of the private sectors, NGOs, and groups of people with the states and complexity of the interactions. This, in turn, has led to a kind of knowledge-based and goal-oriented diplomacy.

A number of integrated theories have been proposed on international relations. However, there is no a generally accepted theory on international cooperation due to a wide range of theoretical frameworks, ideologies, values, discourses, interpretations, and impressions. All of these theories interpret the cooperation based on their own principles and assumptions that are originated from the ontology, epistemology, and methodology. Concerning the economic development based on the liberalism viewpoint it can be concluded that according to the philosophy and ontology, all the countries are internationally interdependent and if they actively cooperate in political arena, they can determine the global formulations and regulations. However, if they prefer to be inefficient, they should undergo the dominance of the political authorities.

\section{References}

Baharcicek, A. (2001). Psychological Environment of Foreign Policy Making. Turkish Foreign Policy Quarterly, 26, 1-6.

Chu, A. C., Leung, C. K., \& Tang, E. (2012). Intellectual property rights, technical progress and the volatility of economic growth. Journal of Macroeconomics, 34(3), 749-756. http://dx.doi.org/10.1016/j.jmacro.2012.04.002

Dai, X. (2008). Why Comply? The Domestic Constituency Mechanism. International Organization, 59(2), 12-25.

Danilovic, R., \& Joe, C. (2009). The Kantian Liberal Peace (revisited). American Journal of Political Science, 51(2), 18-25.

Eskandar, M. (2008). Take a look at the concept of policy. Journal of Methodology in Humanities, 21, 84-113.

Holsti, K. J. (1982). International Politics: A Framework for Analysis. New Jersey: Prentice-Hall International.

Jack C. P., \& Roy, O. (1988). The International Relations Dictionary (4th ed.), New York: Longman. 


\section{Macrothink

Keohane, R., \& Joseph, N. (1973). World Politics and the International Economic System, the Future of the International Economic Order. Oxford University Press.

Mashayekhi, A. (2013). The main challenges of Iranian economic development.

Morgenthau, H. (1999). The politics among nations. translations H. Moshirzadeh, Tehran: Press center of the Ministry of Foreign Affairs.

Moshirzadeh, H. (2007). The development of theories of international relations, Tehran side.

Rosenau, J. N., \& Mary D. (1995). Thinking Theory Thoroughly-Coherent Approaches to an Incoherent World. Oxford: Westview Press.

Sajjadpour, S. K. (2004). Conceptual frameworks and research to study Iran's foreign policy, the Office of Political and International Studies.

Scadden, A. D. J., \& Smith, C. W. (2001). RNAi is antagonized by A $\rightarrow$ I hyper - editing. EMBO reports, 2(12), 1107-1111. http://dx.doi.org/10.1093/embo-reports/kve244

Schmidt, B. C. (2002). On the History and Historiography of International Relations. In W. Carlsnaes, T. Risse, \& B. A. Simmons (Eds.), Handbook of International Relations. London: Sage. http://dx.doi.org/10.4135/9781848608290.n1

Sergunin, A. (2000). Russian Post-Communist Foreign Policy Thinking at the Cross-Roads: Changing Paradigms. Journal of International Relations and Department, 3(3), 34.

Seyfzadeh, S. H. (2006). Iran's foreign policy in the twenty-year perspective. Political and International Studies.

Suganami, H. (2009). Narrative Explanation and International Relation: Back to Basics. Millennium. Journal of international studies, 37(2).

Sylvan, D. A. (1998). Voss; Problem Representation in Foreign Policy Decision Making. Cambridge: Cambridge University Pres.

Vahidi, M. (2007). Beyond technology and the evolution of power in international relations. Journal of Strategic Studies, 4, 28.

Wagner. R. H. (2008). Theory of International Politics. Chapter 1 in War and the State: The Theory of International Politics. Ann Arbor: University of Michigan Prees.

Waltz, K. N. (1979). Theories of International Politics. New York: McGraw-Hill.

Wohlforth, W. (2008). Realism and Foreign Policy at Foreign Policy Theories, Actors and Cases. Oxford, Oxford University Press.

\section{Copyright Disclaimer}

Copyright for this article is retained by the author(s), with first publication rights granted to the journal.

This is an open-access article distributed under the terms and conditions of the Creative Commons Attribution license (http://creativecommons.org/licenses/by/3.0/). 